\footnotetext{
${ }^{1}$ Animal Science and technology college, Northwest A \& F University, Yangling Shaanxi 712100, China

${ }^{2}$ Institute of Animal Science, Chinese Academy of Agricultural Science, Beijing 100094, China

YAN WU ${ }^{1}$, XIAOLIN LIU ${ }^{1 *}$, SHUISHENG HOU ${ }^{2}$, JIE WANG ${ }^{1}$, YU LIU ${ }^{1}$ and XIANGJIE KONG ${ }^{1}$
}

\title{
An intronic SNP of PPARG and its association with fat traits in four meat-type duck populations (Brief report)
}

(Ein intronischer SNP des PPARG Gens und seine Assoziation mit Fettmerkmalen bei Enten)

Background: Modern strains of ducks exhibit excessive body fat deposition, which is one of the main problems encountered by duck industry today. Excess fat deposition has led commercial breeders to incorporate significant selection for reduced body fatness in breeding programs. Peroxisome proliferators-activated receptors (PPARs) belong to the nuclear receptor superfamily (SCHOONJANS et al., 1996). In particular peroxisome proliferators-activated receptor gamma, PPARG has been implicated in the regulation of lipid metabolism and, consequently, in diseases that involve disturbances in lipid metabolism (obesity, diabetes, atherosclerosis, cardiac failure) (VAN et al., 2002). Thus PPARG is a candidate gene for traits related to fat deposition.

\section{Procedures:}

Primer sequences:

The duck PPARG intron-1 (GenBank accession No. EU168847) gene sequence was used to design 3 sets of PCR primers for SNP discovery and genotyping.

GSP1-F: 5’-ATCAAGCTCCAGGATTGCC -3’;

GSP1-R: 5'- GTGTATGGTGTTTGTTTT -3'

GSP2-F: 5'- AAAACAAACACCATACAC-3'

GSP2-R: 5'- CTAAACTCTACTGGACTC-3'

GSP3-F: 5'-GAGTCCAGTAGAGTTTAG-3'

GSP3-R: 5'-GTAACTTGGTAACCTCTT-3'

The PCR amplification used standard lab protocols. PCR program: initial denaturation for $4 \mathrm{~min}$ at $95^{\circ} \mathrm{C}, 33$ cycles each $30 \mathrm{~s}$ at $95^{\circ} \mathrm{C}, 35 \mathrm{~s}$ at $56^{\circ} \mathrm{C}$ and $30 \mathrm{~s}$ at $72^{\circ} \mathrm{C}$ and 10 min final extension at $72^{\circ} \mathrm{C}$. PCR reactions were carried out in a total volume of $15 \mu \mathrm{L}$ with $40 \mathrm{ng}$ of genomic DNA, $5 \mu \mathrm{M}$ of each of forward and reverse primer, $1.5 \mu \mathrm{L}$ of $10 \times$ buffer, $1.5 \mathrm{mM}$ of $\mathrm{MgCl}_{2}, 0.25 \mathrm{mM}$ of dNTP, and $1.5 \mathrm{U}$ of Taq DNA polymerase. SNP identification, genotyping and association analysis:

The populations used for identification of SNP (single nucleotide polymorphisms) in PPARG intron-1 were Z2 (maternal line), Z4 (paternal line) and hybrid lines of Peking duck and the Cherry Valley duck (in total 384 individuals). By aligned sequences of 3 phenotypes with the PPARG intron-1 sequence, one SNP was found and genotyped in all populations. The growth and fatness traits (including carcass weight, carcass net weight, breast muscular weight, leg muscular weight, abdominal fat weight, sebum weight, percentage of abdominal fat, percentage of sebum, intramuscular fat (IMF)) 
were measured at 42 days of age after slaughtered. Association analysis between the SNP and growth and fatness traits were performed using least square analysis in SPSS 13.0 within each of the four duck populations with genotype as the fixed effect.

Results: One SNP was detected amplified by primers GSP2-F and GSP2-R causes a nucleotide mutation (G878A of EU168847) in the four populations. The genotype BB was not found in the studied populations. Association analysis revealed that the homozygous (AA) birds had significant lower leg muscular weight than heterozygotes $(A B)$ in Z2. The heterozygotes (AB) had higher IMF than homozygotes (AA) in the Z4 and Cherry Valley duck populations. For the hybrid Peking duck population, the homozygotes (AA) had significant higher sebum weight and percentage than heterozygotes (AB) (Table). Furthermore, no significant associations of different genotypes with other traits were detected $(\mathrm{P}>0.05)$. So, we conjecture PPARG gene may be a major gene or linked to the major gene that impact lipid metabolism and the SNP could be used in marker assistant selection (MAS) as a genetic marker for the duck fatness traits. In the future, more samples will allow precise estimates of the association of the SNP on the growth and fatness traits in ducks.

Table Least square analysis between intron-1 of PPARG gene and growth and fatness traits in ducks

\begin{tabular}{llll}
\hline \multicolumn{2}{c}{ Population } & \multicolumn{1}{c}{ Traits } & \multicolumn{2}{c}{ Genotypes } \\
\cline { 3 - 4 } & & \multicolumn{1}{c}{ AA } & \multicolumn{1}{c}{ AB } \\
Z2 & Leg muscular weight (g) & $121.3 \pm 1.6^{\mathrm{b}}(\mathrm{n}=38)$ & $142.9 \pm 9.3^{\mathrm{a}}(\mathrm{n}=57)$ \\
$\mathrm{Z4}$ & Intramuscular fat (\%) & $6.29 \pm 0.20^{\mathrm{B}}(\mathrm{n}=49)$ & $7.20 \pm 6.64^{\mathrm{A}}(\mathrm{n}=49)$ \\
Cherry Vally duck & Intramuscular fat (\%) & $3.86 \pm 0.11^{\mathrm{b}}(\mathrm{n}=37)$ & $4.29 \pm 0.11^{\mathrm{a}}(\mathrm{n}=62)$ \\
Hybrid Peking duck & Sebum weight (g) & $632.8 \pm 13.7^{\mathrm{a}}(\mathrm{n}=43)$ & $591.7 \pm 10.4^{\mathrm{b}}(\mathrm{n}=49)$ \\
& Percentage of sebum (\%) & $56.75 \pm 1.15^{\mathrm{a}}(\mathrm{n}=43)$ & $53.42 \pm 0.99^{\mathrm{b}}(\mathrm{n}=49)$ \\
\hline
\end{tabular}

Note: Small letters (a, b) denoted significant difference $(\mathrm{P}<0.05)$; capital letters $(\mathrm{A}, \mathrm{B})$ denoted highly significant difference $(\mathrm{P}<0.01)$; $\mathrm{Z} 2=$ Peking duck Z2; Z4 = Peking duck Z4.

\section{Acknowledge:}

The author would like to thank Institute of Animal Science of Chinese Academy of Agriculture Science for collecting samples.

\section{References:}

SCHOONJANS, K.; STAELS, B.; AUWERX, J.:

The peroxisome proliferator-activated receptors (PPARs) and their effects on lipid metabolism and adipocyte differentiation. Biochim Biophys Acta. (1996)1302: 93-109

VAN, B. M.; VAN, V. G. J.; GILDE, A. J.; LINDHOUT, M.; VAN, K. A. J. M.:

Peroxisome proliferators-activated receptors: lipid-binding proteins controlling gene expression. Molecular and Cellular Biochemistry. 239 (2002) 1-2, 131-138 